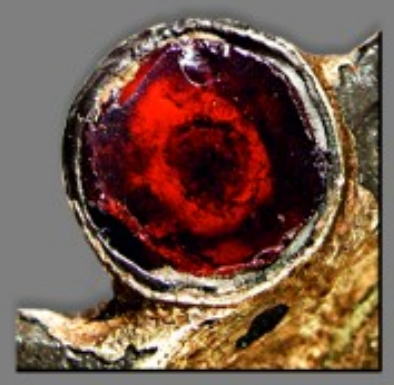

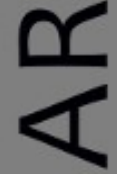

$\sim$

ш
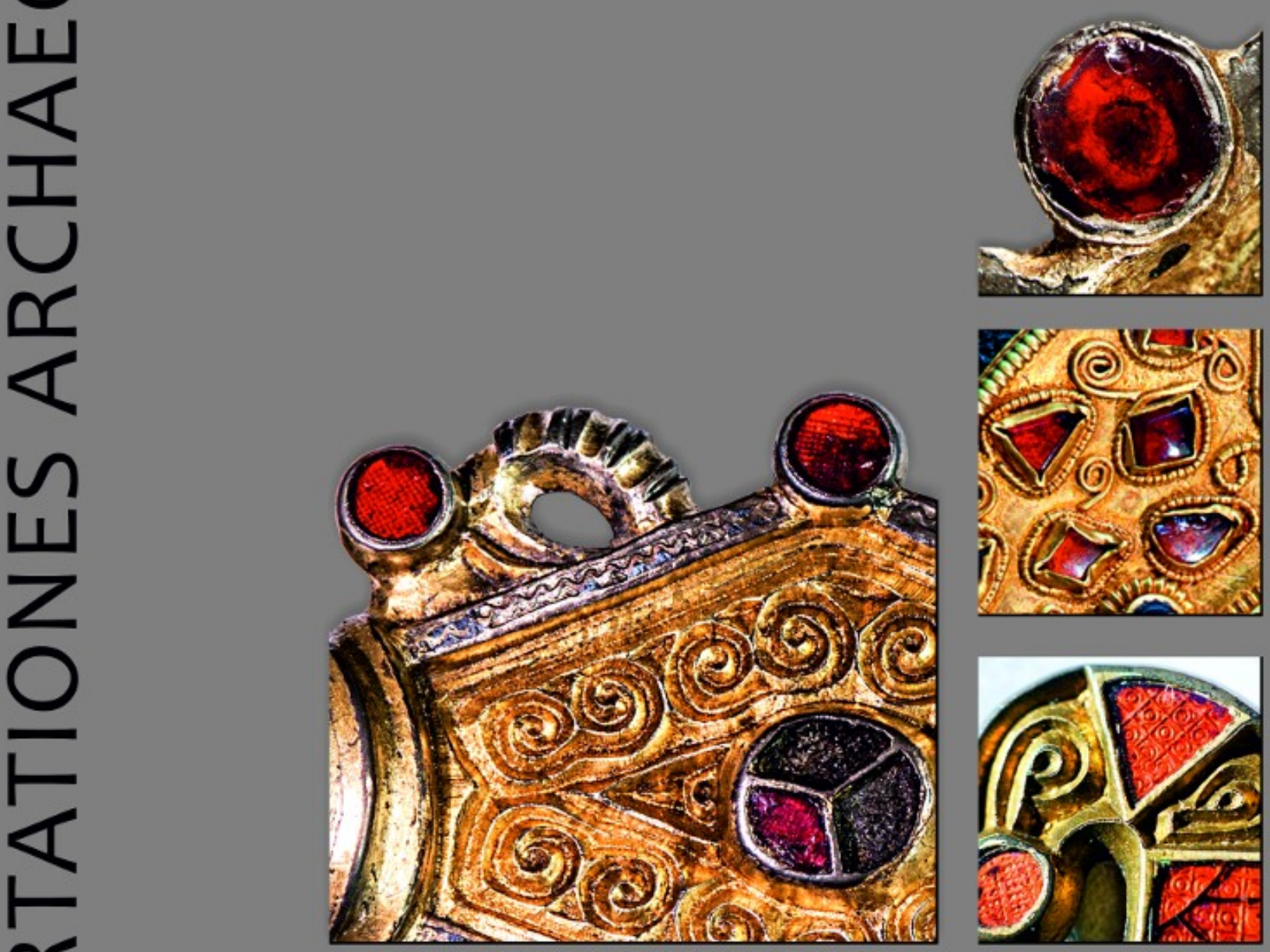

E

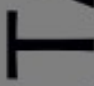

œ

山

n

ก

$\overline{0}$
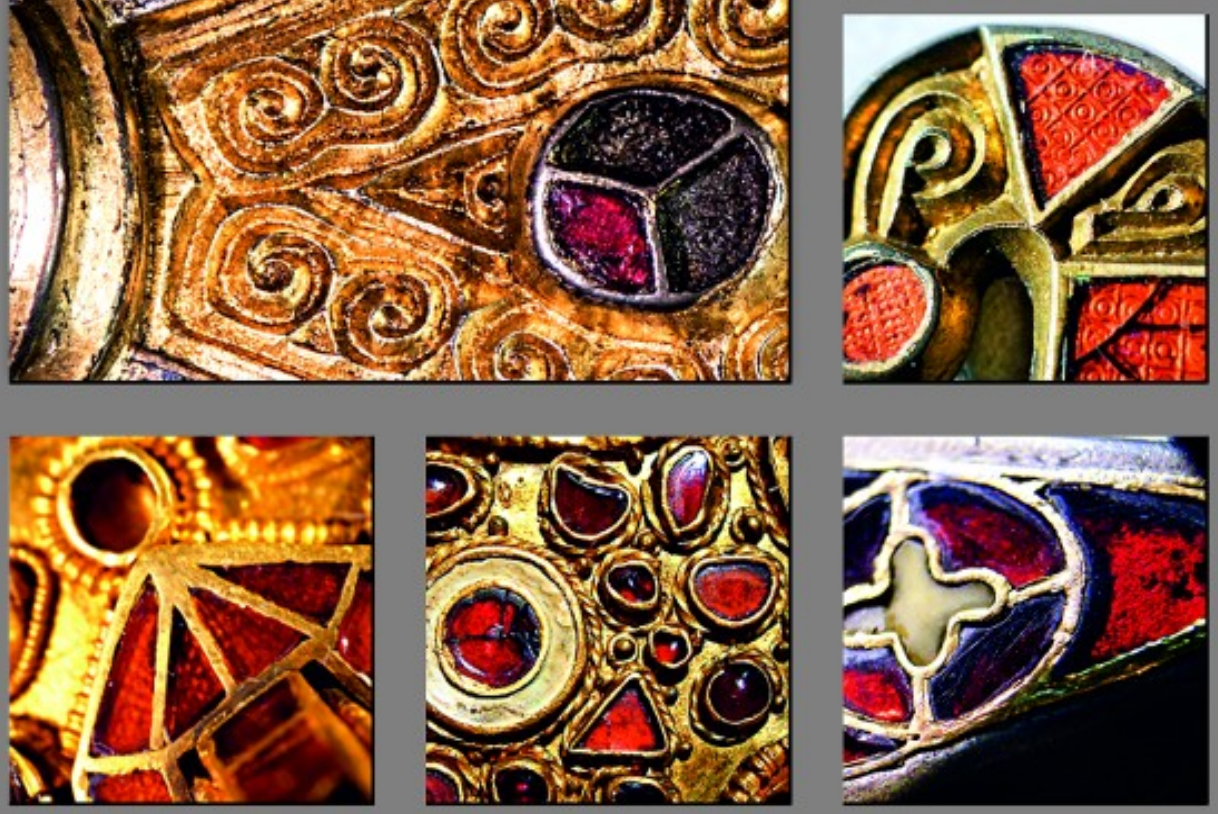

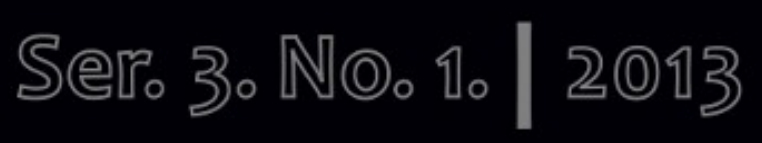




\section{Dissertationes Archaeologicae ex Instituto Archaeologico}

Universitatis de Rolando Eötvös nominatae Ser. 3. No. 1.

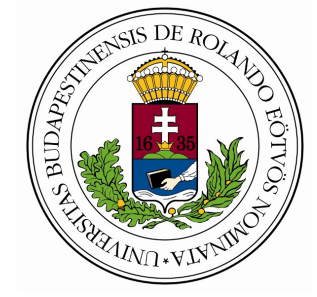

Budapest 2013 
Dissertationes Archaeologicae ex Instituto Archaeologico

Universitatis de Rolando Eötvös nominatae

Ser. 3. No. 1.

Editor-in-chief:

DÁvid BARTUS

Editorial board:

LÁSZLÓ BARTOSIEWICZ

LÁSZLÓ BORHY

ISTVÁN FELD

GÁBOR KALLA

PÁL RACZKY

Miklós SzABÓ

TIVADAR VIDA

Technical editors:

DÁvid BARTuS

GÁBOR VÁCZI

ANDRÁs BöDŐcs

Proofreading:

Zsófia KondÉ

SzILvia SzÖLlősI

Available online at http://dissarch.elte.hu

Contact: dissarch@btk.elte.hu

\section{$\underline{\text { PKP }}$ \\ PUBLIC \\ KNOWLEDGE \\ PROJECT}

(C) Eötvös Loránd University, Institute of Archaeological Sciences

Budapest 2013 


\section{Contents}

\section{Articles}

Melinda TORBÁGYI - István VIDA

The coin hoard of Abasár

Anikó BózsA

21

Roman mirrors from a private collection in the Hungarian National Museum

Lajos JuHÁsz

45

The Biesheim cameo - a reinterpretation

\section{Methods}

Péter CsIPpÁN

$A z$ állatcsont, mint információhordozó leletanyag

Kata DÉvAI

Terminológiai alapfogalmak régészeti korú üvegtárgyak elemzéséhez

Lőrinc TimáR - Zoltán Czajlik - Sándor Puszta - Balázs Holl

$3 D$ reconstructions using GPR data at the Mont Beuvray

\section{FIELD REPORTS}

Zsolt MESTER

Excavation at a new Upper Palaeolithic site of the Eger region (Northern Hungary)

László BORHY - Dávid BARTus - Emese SzÁmadó

Short report on the excavations at Brigetio (Szőny-Vásártér) in 2013

Dénes HulLÁm - Zsófia RÁcz

Report on the participation of the Eötvös Loránd University at the Wielbark Archaeological Field School in Malbork-Wielbark, Poland

Gábor VÁczi - Dávid BARTus

Short report on the excavations at the site Makó - Igási Ugar

Maxim MoRdovin

Short report on the excavations in 2013 of the Department of Hungarian Medieval and Early Modern Archaeology (Eötvös Loránd University, Budapest)

\section{THESIS ABSTRACTS}

Kitti KÖHLER

Biological reconstruction of the Late Neolithic Lengyel Culture 
Cultural connections and interactions of Eastern Transdanubia during the Urnfield period

Orsolya LÁNG

Urban problems in the civil town of Aquincum: the so-called „northern band”

Nikoletta SEY

Questions of bronze workshops in Roman Pannonia

Kata DÉvaI

Glass vessels from Late Roman times found in graves in the Hungarian part of Pannonia

Eszter HORvÁTH

Gemstone and glass inlaid fine metalwork from the Carpathian Basin:

the Hunnic and Early Merovingian Periods

Gergely SzEnTHE

Vegetal ornaments in the Late Avar decorative art

Péter LANGó

Relations between the Carpathian Basin and South East Europe during the 10th century.

The evidence of the minor objects

Ciprián HoRvÁTH

The Cemeteries and Grave Finds of Györ and Moson Counties from the Time

of the Hungarian Conquest and the Early Árpádian Age

András Sófalvi

The border- and self-defence of Szeklers from the Medieval Age till the Age of Principality.

Castles and other defence objects in the settlement history of Udvarhelyszék 


\title{
The Cemeteries and Grave Finds of Gyór and Moson Counties from the Time of the Hungarian Conquest and the Early Árpádian Age
}

\author{
Ciprián HoRvÁth \\ Ministry of Interior \\ Department for Heritage Protection \\ ciprian.horvath@gmail.com
}

\begin{abstract}
PhD thesis submitted in 2013 to the Archaeology Doctoral Programme, Doctoral School of History, Eötvös Loránd University, Budapest under the supervision of Tivadar Vida.

The dissertation examines the burials of the territory of two counties, Gyor and Moson in the west of the Hungarian Principality in the age of the Hungarian Conquest, and the Hungarian Kingdom in the Early Árpádian Age. Their analysis will be the ground for sketching the picture of the territory in the 10th-11th centuries. First the period's sites are presented, then the assessment of individual phenomena and object types follows, providing ground for the examinations of the history of settlements, which partly leads through the examination of the borderland character of the territory. The territory of the former two counties forms the geographical frames. The temporal frames are formed by, on the one hand, the occupation of Transdanubia in - according to our present knowledge - 900 and on the other hand, the end of the 11th century and the beginning of the 12th century.
\end{abstract}

\section{Natural geographical environment}

The two counties found in the Kisalföld major region of the Danube Basin are bordered by the Danube on the North, which is touched by all the three middle regions of the major re gion, the Győr Basin, the Komárom-Esztergom Plain and the Marcal Basin. Regarding their soil conditions, the different alluvial soils are typical, their climate conditions reveal a picture similar to those of our day. The most important among the natural geographical conditions were the hydrographical conditions. Before the river controls this country was rich in marshes and swamps, often exposed to flood danger, having territories covered with contiguous water, lying in the windiest part of Transdanubia.

\section{The history of research of cemeteries and burial sites}

We have had information concerning the provenience of the territory's first graves of this period since the middle of the 19th century, but at that time we can only reckon with the conservation of some parts of findings coming from graves uncovered by chance. The first known site is the Győr-Újszállások graveyard, from which finds could have turned up even at the end of the 1850s and at the beginning of the '60s. Nevertheless the first burials, the finds of which could have got to public collections, even with record and publication in 1865 in Pannonhalma, were found in the same year in Koroncó. It had a great importance for the research of the period that on Flóris Rómer's initiative the Archaeological Laboratory was 
formed in the Benedictine Grammar School in Győr in 1859, giving a significant momentum to interest toward archaeology. Moreover, beside Archaeologiai Közlemények then Archaeologiai Értesitó, the publication of the finds found place in the bulletin of the Laboratory, the annual reports informing about the growth of the Laboratory as well. In 1890 Ágost Sóter began the excavation of the graveyard with the highest grave number in Moson county on Wiesenacker-dülö, in Oroszvár (Rusovce), which he continued in 1903, Nándor Fettich in 1938, while Árpád Bottyán and János Nemeskéri in 1942-43. In particular at the beginning of the 20th century many graves and graveyards turned up, the rescue and the publication of the majority of them is connected to Arnold Börzsönyi. The leader of the collection of the Benedictine Grammar School searched on Győr-Téglavető-dűlő, in Mosonszentmiklós, Gyömöre, and Nyúl-Öreghegy as well. Béla Cigány, school- and headmaster in Koroncó then in Győr, rescued finds on Koroncó-Rácz-domb in 1934, then in 1936 in Csikvánd. The works of Elemér Lovas is of great importance too, who - beside his excavations - drew up the archaeological cadaster of Győr county, published the history of archaeological collection of Győr and presented the historical geography of Koroncó. At the end of 1946 Béla Szőke went to Győr and became the curator of the Museum of Győr. His synthetic works are of the greatest importance among his works, in which he regarded and analysed the entire territory of the Kisalföld as a whole. He devoted a separate study to the history of Győr during this period, and dealt with the history of Kisalföld in the 9th-10th century in a separate study too. In his work, decisive up to this day, published in 1962 and entitled "The Archaeological Relics of the Hungarians in the Age of the Hungarian Conquest and the Early Árpádian Age", he based his analyses on several finds of the Kisalföld.

In his cadaster of finds, published the same year as the second volume of the Régészeti Tanulmányok, referring to collections till 1959 and entitled "The Grave Finds in the Age of the Hungarian Conquest and the Early Árpádian Age in the Middle-Danube Basin”, 28 sites originating from this period can be found in Győr-Moson county. The research of the period owes much to Rezső Puszta's activity too, who, made rescue excavations on Pusztasomorja-Tímár-domb with smaller interrupts between 1965 and 1970. In 1968 and 1974, he rescued graves on the main square of Levél village. In 1960 on the inner territory of Öttevény, András Uzsoki excavated a horse grave, and in 1968 he worked together with Károly Kozák in the the Early Árpádian age graveyard of Győr Cathedral. They excavated graves originating from the same period with the leadership of Eszter Szőnyi and Péter Tomka. The Lébény-Kaszás graveyard containing 98 observed graves excavated in 1991-92 is attached to Tomka's name as well. Recently a graveyard with small grave number was excavated in Győrszentiván-Károlyháza with the leadership of Szilvia Bíró. The finds and documentation of these graves and graveyards can be found in the collections and archives of BGLM, HM, MNM and XJM. Furthermore, we used relevant data of the heritage of Géza Fehér, Nándor Fettich, János Nemeskéri, Aladár Radnóti and Béla Szőke.

\section{Grave goods of the Hungarian Conquest and the Early Árpádian Age}

The basis of the dissertation is the analysis of the presented graves and cemeteries. 18 sites are presented, which were only known till now from preliminary articles or excavation reports, 8 sites were unpublished, and 23 sites are republished here critically . Thus the analysis will be based on at least 520 graves from 50 sites. Unfortunately the sites are unearthed 
poorly. Altogether the excavation of two cemeteries and three so-called solitary graves can be regarded as authentic and complete. The material of the individual graves only partly known from the reports has further declined to our day, the material of at least 25 sites is damaged, unfortunately several times, thus in some cases the whole find material has disappeared or perished.

The presentation of the sites was carried out as follows: first a report was made of the circumstances of the finding, then followed the grave and find description, the assessment, and finally the relevant archival indexes and those of the archaeological literature. The EOV maps can be also found here, as well as the eventual cemetery maps and other figures relating to the topography of the sites.

\section{The assessment of the finds}

The fact that some burials were not excavated by specialists, and the partial destruction of the sites have made it very difficult to draw a consequence regarding the structure and chronology of the cemeteries. The number of the anthropological data is also low.

As far as the geographical conditions of the region are concerned, the cemeteries and graves are generally situated on smaller moulds, which practice was common in the Carpathian Basin in the 10th-11th centuries. In known cases the sites can be found on moulds $0.5-5 \mathrm{~m}$ higher than their environment, or on smaller terraced hillsides. In case of hills, they found their places on their ridge, or on the northern slope, and if they were near to water, their distance from it could expand from $60-70 \mathrm{~m}$ to as much as half a $\mathrm{km}$. More rarely they can turn up on plain territories, some sites however can be found near the Danube, on terraced high banks or on smaller cones made from stream deposit.

The sites can be divided into three groups: the solitary graves, the so-called raw cemeteries, and the graveyards around churches. Three graves can be ranked among the first group, while four sites came to light around a church. Unfortunately among the so called raw cemeteries - which is the biggest group - only Győrszentiván-Károlyháza and LébényKaszás can be considered fully and authentically excavated, while the biggest known cemetery of Moson county, Oroszvár (Rusovce) is only known in parts. A ditch bordering the cemetery can be observed in only one case.

In most cases, the diseased were buried in a simple, rectangular-shaped grave, with rounded corner, and the orientation of the skeletons were adjusted to the main West-East direction. Neither graves with niche nor with sidewall niche were found; meanwhile graves with berm can be observed in five cases. No clue refers to grave monument, and the stone- or tailed roof graves are missing as well. The interpretation of the graves with stones in them is uncertain. In some graves of the Lébény-Kaszás and Mosonszentmiklós-Lednice-domb cemeteries the diseased were laid on an embanked layer. The wooden remains found during the excavation or the discolourations caused by them could refer to a coffin, but unfortunately not in a way in any case that would have made a reconstruction possible. Nevertheless it can be stated that metal nails, clamp-irons were only rarely used to it.

The diseased were laid in the graves on their back, in stretched position, which was general at that period. More differences were observable regarding the limbs. One prone burial and two in contracted position are known. One of the latter turned up from Grave 44 in Lébény, 
which was one of the burials providing the richest metal finds, querying thus the hypothesis that persons buried in contracted position could have been of servile state. Trepanation can be documented only in two graves in Lébény.

Clue referring to contemporary plunder is not known, superposition was only observable in Graves 171 and 172 in Oroszvár (Rusovce); the latest was presumably an after burial. Adult women and children lied in five graves, but for lack of genetic examinations, we can only render it probable that these graves hid mothers and their children.

The diseased were laid generally in the middle axle of the grave. Only one empty tomb is known, the explanation of which needs further research. But on the territory in question it can be excluded that they were cenotaphs of armed men fallen abroad.

The individual object types - in known cases - were generally found in the place according to wearing customs, there are only two graves where accessories thrown into the grave were found.

Food or drink supplements come from 76 graves of six cemeteries, in majority referred to by clay pots once holding them. This custom is known in great number from the Oroszvár (Rusovce) cemetery, where 35\% of graves included pottery, which is without parallel till now in the cemeteries of the Hungarian territory.

The number of coins is 14, coming from six sites, five graves, and as stray finds in two cases, furthermore 3 of them originate from unknown sites. Unfortunately the type of only 10 of them can be determined. Among them the coins coming from the time of the Hungarian incursions and of the Early Árpádian Age should be separated; which did not turn up together from any grave - or even any cemetery - from the area of these counties.

Among the finds, the different types of lockrings are the most frequent. The separation of their simple, penannular version is often rendered more difficult by the fact that in the case of pieces found without knowing their position in the grave, their use as ring can also be supposed, furthermore, the use of jewelleries as lockring or earring cannot be separated in every case. The simple, penannular wirerings and the S-terminalled rings were most frequently worn, but sometimes the coiled, one and a half fold, S-terminalled, broadening downward lockrings with spiral pendant can also be observed.

Earrings are known from seven graves, in greatest number the earrings with cast-beadrow pendent type are known, among them the earrings from Grave 47 of Győr-Téglavető-dülő were connected by chain. The crescent-shaped earring with chain pendent decorated with filigrane and granulation having turned up from Grave 68 in Oroszvár (Rusovce) is unique.

Twenty-two are known of the characteristic jewellery type of the so-called commonalty cemetery, the collars, from female or child graves in the determinable cases. Beside one piece made of a single wire and one cast example imitating twist, each one is twisted of bronze wire, and four of them is supplemented by filigrane.

The types of pearls show a great variety, nevertheless pearl made of metal is not known. Cowries, smaller snails occur, while lunulas and animal teeth are known only in a smaller number. 
Only one braid ornament made of sheet is known, the parallels of which have only been reported till now from sites east of Danube.

The find material includes a variety of bracelet types; band-, wire- and animal-headed pieces can be found as well. Bronze wire bracelets of round or oval cross-section are present in the greatest number, 12 were found in graves and 23 as scattered finds. They were mainly worn by women, wire bracelets of round cross-section came to light in six graves, while the number of child graves is three, and there is only one male burial. Seven examples of wire bracelets of square cross-section are known. Among the twisted bracelets, pieces spirally filled on both ends,loop-in-loop and hooked terminalled can be found equally. Band bracelets turned up from five graves and in two cases as stray finds, altogether in seven samples, in bronze and silver version, in each case from female graves. Among the six pieces of animal-headed bracelets only one, the jewellery of the Grave 17 in Bácsa comes from authentic excavation.

Among the rings almost every type characteristic of the age can be found; two ball-headed rings, one equipped with bronze ring and silver framework and the one from Grave 200 of Oroszvár (Rusovce) ornamented with filigrane and granulation are outstanding.

Unfortunately the belt mounts of all the three sites can be considered stray finds, among the dress fittings some smaller pieces having one and two parts, one piece of secondary use with a bigger pendant, and two pieces of square-shaped mounts are known. The use of metal buttons was less characteristic, since bronze or silver buttons turned up from only seven graves. Two so-called Moravian ornamental buttons are documented, they turned up from Grave 68 of Oroszvár (Rusovce) containing the earlier mentioned crescent-shaped earrings with chain pendants. The number of weapons is low, beside the only - though unique till today - single-edged sword, the elements of archer equipments can be mentioned. It should be noted that boned bows have not been found till now.

Among the horse graves the harness mounts with rosette should be highlighted, the gathering of which in the Koroncó area is overmuch remarkable. Horse bits and bridle bits of a foul, furthermore different types of stirrups can equally be found, one of them is decorated with trapezoid metal inlay.

\section{Territorial examinations}

\section{Chronological examinations}

I have rated the graves and cemeteries into three chronological sections. The first one is the 10th century including all the horse graves and solitary sites, or sites with only a few graves, mainly situated between the Rába and Concó brook or along the Moson-Danube. The grave number of the cemeteries originating from the 10th-11th centuries is seven, but because of the cemeteries with higher grave number, the majority of graves belongs here. The so-called commonalty graveyards are found along the Danube and its Moson arm. The 11 th century is represented by 11 sites; however, most of them are sporadic. 


\section{The ethnical examination of graves and cemeteries}

Nowadays the possibility of ethnical determination is one of the most disputed questions of archaeology. It reckons with the possibility of the presence of more ethnic groups, on our examined territory as well. On the basis of written sources and toponymic data the research reckons with the settlement of Petchenegs in four separated territorial blocks. No such archaeological source turned up on these territories - not even on the whole territory of the two counties either - on the basis of which their presence would be supposable. The examination of the 10th-11th century graves found in the Avar Age cemetery of Győr-Téglavető-dülő brought negative results as well; they cannot be regarded as a proof of a surviving Avar population. Regarding the Oroszvár (Rusovce) cemetery, the written sources and the toponymic data raise the question of the presence of a Russion population, while a part of the archaeological finds seem to refer to a surviving population from the 9th century. With archaeological methods no Eastern Slavic population could be detected in the cemetery, and there are also only some vague traces referring to a population dwelling here in the century preceding the Hungarian Conquest, without helping to solve the question unambiguously.

\section{Microregional examinations}

These examinations separated two minor regions, the Győr and Koroncó areas, and as far as our definition is correct, they cannot be identified with the natural geographic borders in every case. On the basis of a larger examination it can be seen that the majority of sites can be found on the territory of Moson county, but in spite of that it is quite evident that we can reckon with a settlement structure one similar to that of the Hungarian territories and the later territories of the Hungarian Kingdom up to the Leitha.

\section{Archaeological data to the history of Györ and Moson counties}

In this chapter we try to provide data to the history of the two counties and that of the western part of Transdanubia in the Age of Conquest and the Early Árpádian Age with the help of presented source basis.

\section{The question of borderland}

Regarding the 10th-11th centuries the first and most important question is the methodological problematics of the border. Its examination is be followed by the analysis of natural geographic and toponymic data, then I examine the topographical situation of the sites of the western region with their character and finds, representing their situation in a map as well. They are ranked in three chronological units too, like in the case of Győr and Moson counties. On its basis it can be seen that the Moson county group of 10th century sites is connected with those of Sopron county from the Southwest. Regarding their topographic situation, the great majority of the sites from the 10th century is situated in the Rábaköz, south of Hanság, their westernmost occurrence is Szakony and Röjtökmuzsaj. Cemeteries providing richer finds are characteristic of the Rábaköz too, and especially of its western part. In Vas county two blocks of them seem to stand out, one is the territory between Pinkaóvár (Burg) and Vasasszonyfa, the other is east of the Rába river, in the Celldömölk area.

In the case of graves and cemeteries from the 10th-11th centuries, compared with the block of those in Rábaköz from the 10th century, a swing to the west can be observed, and a site is 
known even from the northwestern part of Lake Fertő. In the 11th century cemeteries turn up farther in the west, up till the Pecsnyéd (Pöttsching) - Középpulya (Mittelpullendorf) line, approximately in territorial equipartition. On the territory of Vas county, in the case of the 10th-11th century cemeteries this significant swing to the west cannot be observed compared with those from the 10th century. In Zala county the sites dated from the period beginning with the middle of 10th century can be found in the northeastern part of the county, near Zala Valley, or near the Kis-Balaton.

Regarding the settlement territory of the 11th century, a swing to the west can be observed in Sopron county, which is however not characteristic of Vas county. Meanwhile, in the case of Zala county, sites can be found in the west, as far as the Válicka Valley.

As far as the types of cemetery structures are concerned, the so-called commonalty cemeteries with a greater grave number can be found on the whole examined territory, even though not in the same proportion. The graveyards providing ampler finds with smaller grave number - at most 30-40 graves - are known till now only from Sopron county. Whereas the solitary ones often containing bridle ornament with rosette as well, are rather typical of the Győr area.

Regarding the finds, it is widely known that Transdanubia is deficient in those object types which can be ranked among the so-called dominant types of the Age of Conquest. The bridle ornaments with rosette are the only exceptions. The metal brade ornaments are rare, the metal dress fittings are scanty, and only some sites of belts decorated with mounts are known. More conspicuous is the almost entire lack of the double-edged swords and the trapezoid stirrups, though the lack of the object types spreading from the middle of the 10th century can be caused by the diverse representation as well. Nevertheless the sables used already from the first half of 10th century are scarce, which - even if the early spread of diverse representation is taken into consideration, at least in the beginning of the century could have got into graves at that time.

On the basis of the above mentioned arguments it is probable that the Hungarians of the 10th century appeared earlier in the areas south of the Danube than in the central and southern part of Transdanubia. Beside the possibilities provided by the natural geographic conditions the reason could also be geopolitical, that the Hungarians, similarly to the Avars, regarded the Danube Valley as the most vulnerable part of their whole territory, which needed to be strengthened.

\section{The so-called connection zone}

In a geographical sense the so-called connection zone means the territory where the neighbouring political powers can be in contact with each other. It is in present case the Ostmark, on the South the Caranthane Principate and the Hungarian Principate, the later Hungarian Kingdom. During the examination, both the archaeological sources of the Carpathian Basin showing western European influence, and its opposite, the Eastern Alpine occurrence of the Hungarian-like finds or/and ritual elements should be scrutinized. Through the analysis of these two will be outlined the phenomena caused by the cultural relations.

Beside the objects which can be regarded as uncertain or transitional types, and the exception of those not needing any particular archetype because of their very simple solution; the button ter- 
minalled rings, the fibulas and the earrings with engraved pattern or with enamel inlay can be ranked here. In the greatest number the button-terminalled rings are known. 38 pieces have turned up from 29 graves and as stray finds, and they can be ranked among four categories. They were used as head jewelleries, bracelets or rings. The crescent-shaped earrings are known from 14 sites, which can be ranked among two main groups on the basis of their ornaments: the pieces with enamel inlay and with engraved pattern; the previous can be ranked among two further subcategories. Fibulae turned up from 11 sites and because of their various forming, almost each one belongs to a separate group. Button terminalled rings have the earliest occurrence, among them especially the ones with longer diameter, which could have appeared in graves already in the middle of the 10th century, while the ones with shorter diameter could have got into graves from the last quarter of the century. The earrings could also have appeared in graves from the $970 \mathrm{~s}-980$ s, while the fibulas can be dated from the turn of the millennium. Regarding the occurrence of these objects, the rate is in $70 \%$ female, in $22 \%$ infant and in $8 \%$ male grave in the known cases. We can notice a certain site concentration on the northern shore of Balaton, on the territory of Győr, Moson, Sopron, Vas, Baranya, and Heves counties; however, it can also be caused by the different research processes. As far as both the way of wearing and the combination of the certain object types are concerned, Eastern Alpine parallels can be detected. The Hungarian-like object types and ritual elements are known from 6 sites; they are mainly the smaller monomial mounts or mounts with pendant, collars, bracelets, lunulas, earrings and food or drink furniture. Fashion, commerce and ethnical identity also arose in the archaeological literature. In general it can be said that in spite of observable bilateral connections, one cannot speak of the formation of a contiguous zone - or at least it cannot be justified with archaeological methods - where in the place of the encounter of the two cultures a third one would have come into existence with a special and unique profile, as it was observable in the case of Pannonia in the 9th century. 